An important resolution from the African section dealt with the desirability of establishing a Congress of Africanists, to be held in the various capitals of the new African states:

'The African Section of the XXVth International Congress of Orientalists, in view of the growing importance of African studies resolves :

(I) That it is desirable to extend the work of the Section by establishing an International Congress of Africanists.

(2) That the initial meeting of this Congress be held in one of the African University centres, if possible in 1962 .

(3) That, with their consent, a Committee of Organization composed of the heads of the National University of Mali, the University College of Ghana, the University College of Ibadan, the University of Addis Ababa, the University of Tunis, and the head of one Congo University, plus representatives of the International African Institute, the Africa Institute of the Academy of Sciences of the USSR, the African Studies Association of the United States of America, and of the French Africanists be appointed, with the Principal of the University College of Ibadan as chairman.

(4) That the Chairman of the present Section be requested to communicate with the above-mentioned individuals and bodies so as to facilitate the formation of the Committee on Organization.'

The Ethiopian delegate, Tekle Tsadik Mekuria, said that his country would in all probability be glad to invite the first Congress. At the same time it was felt that the African Section of the normal Congress of Orientalists should continue.

(Communicated by Professor A. N. Tucker and Dr. A. N. Allott)

\title{
Leverhulme History Conference at the University College of Rhodesia and Nyasaland, S-Is September 1960
}

THE main aim of this Conference, as of all the conferences being organized as a result of the Leverhulme Trust grant, was to provide an opportunity for scholars engaged in research and teaching within the same disciplines in tropical Africa, where the university community is so fragmented by distance, to meet each other. Most of the delegates to the Conference were members of the history departments of universities and university colleges from the Sudan, Ethiopia, Kenya, Uganda, Sierra Leone, Ghana, and Nigeria. Representatives from Dakar and the Congo were unable to be present. In addition, the Conference was attended by Dr. Ronald Robinson of Cambridge, Professor L. M. Thompson of Cape Town, Mr. George Shepperson of Edinburgh, and Professor I. Schapera and Dr. Roland Oliver of London. Scholars working in the linguistic, archaeological, and anthropological fields within Central Africa itself were also present.

The initial discussions on the interrelation of historical research with work in other fields were concentrated on Central and East Africa and provided an excellent introduction to a visit to the sites of Zimbabwe and Inyanga under the guidance of Mr. Roger Summers, and to the Stone Age sites at the Victoria Falls under the guidance of Mr. Desmond Clark.

One particularly interesting feature of these discussions was the general agreement of the conclusions drawn by Mr. Summers through the use of archaeological techniques with those drawn by Mr. D. P. Abraham through the use of an analysis of oral traditions concerning the kingdom of Monomatapa. It appeared possible, also, that the tentative results produced by Professor G. Fortune's application of certain linguistic techniques to the Shona language group could be taken to reinforce the conclusions drawn by Mr. Summers and Mr. Abraham. Central African studies, therefore, provided an encouraging example of the potentialities of co-operation between disciplines which was one of the themes of the Conference. 
The question of the utility of oral tradition was discussed at length. In this connexion the Conference was impressed by the rigorous rules drawn up by Dr. J. Vansina for the collection and interpretation of oral evidence, and came to the unanimous conclusion that work of this kind should be encouraged in every way possible.

Most of the papers contributed to the Conference illustrated the new concern with a more balanced view of African history by emphasizing the importance of the reaction of African societies to the impact of European formal and informal empire; by making use of hitherto unexploited documentary sources, Islamic sources in particular; by making use of oral tradition; by re-examining sources already used with different questions in mind, and so on. It is hoped that the papers-together with an editorial abstract of the main points raised in discussion-will be published in some form.

[Communicated by Mr. Terence Ranger]

\section{Staff Problems in Tropical Countries}

THE International Institute of Differing Civilizations held its 32 nd study session in Munich from 19 to 22 September, on the subject of 'Staff Problems in Tropical and Sub-Tropical Countries'. The discussions were introduced by five general rapporteurs: M. Georges Balandier (France), Director of Studies at the École Pratique des Hautes Études (social aspect); Dr. J. S. Coleman (U.S.A.), Professor of Political Science in the University of California (legal aspect); Sir Sydney Caine (U.K.), Director of the London School of Economics (economic aspect); M. Gabriel d'Arboussier (Mali), former President of the Grand Conseil de l'Afrique Occidentale Française (political aspect), and M. Charles Ammoun (Lebanon), Lebanese delegate at UNESCO (cultural aspect). These reports were based on some thirty regional papers from the main Asian, African, and American countries. Discussions were led by Dr. Wolfgang Pohle, President of INCIDI.

\section{L'Institut des Sciences Economiques et Commerciales Appliquées de l'Afrique Noire (Dakar)}

L'Instritut des Sciences Économiques et Commerciales Appliquées de l'Afrique Noire a été créé en 1959. C'est un Institut d'Université dirigé par un professeur de la Faculté de Droit et des Sciences Économiques de Dakar, qu'assiste un Conseil de Perfectionnement placé sous la présidence du Recteur de l'Université. Les buts de l'Institut sont l'enseignement, la recherche, et la liaison avec les Institutions étrangères et les organisations internationales. $\mathrm{La}$ tâche $\mathrm{la}$ plus urgente était relative à l'enseignement. En effet, le personnel économique et commercial d'origine africaine est encore peu nombreux, et l'Indépendance en appelle l'accroissement accélété. L'Université ne peut fournir, et pour longtemps encore, qu'une quantité restreinte des spécialistes en question.

Il y a deux sections de l'Université. La première, dite Section Économique et Commerciale, s'efforce d'apporter à nos auditeurs un complément de formation leur permettant d'accéder à des fonctions supérieures. La seconde, dite Section Statistique, d'un niveau plus relevé, vise à former des statisticiens qualifiés. Deux nouvelles séries seraient ajoutées l'année prochaine. La première, s'adressant aux diplômés de la Section Économique et Commerciale, aurait pour objet de les perfectionner dans l'examen des problèmes concrets qui se posent, soit aux directeurs d'entreprises, soit aux responsables de l'Économie nationale. La seconde viserait les animateurs affectés par l'Administration au développement régional et local et leur inculquerait les connaissances fondamentales sur lesquelles doit s'appuyer leur action (ceci à la demande même du Ministère du Développement du Sénégal). Il entre aussi dans 